\begin{tabular}{|c|c|c|c|}
\hline KULTURA & $\begin{array}{l}\text { POLSKA } \\
\text { KOMITET } \\
\text { INSTYTU }\end{array}$ & $\begin{array}{l}\text { AKADEMIA NAUK } \\
\text { SOCJOLOGII } \\
\text { T STUDIÓW POLITYCZNYCH }\end{array}$ & ISSN 0023-5172 \\
\hline & 2015 , nr 3 & ARCHIWUM I Z & $\mathrm{ZPO}$ \\
\hline
\end{tabular}

KATARZYNA CHAJBOS, WALDEMAR RAPIOR

Uniwersytet im. Adama Mickiewicza w Poznaniu

\title{
UPUBLICZNIENIE NIEWIDZIALNEGO: ARCHIWUM WIZUALNE I INTELEKTUALISTA-PRAKTYK
}

„Zobacz kulturę. Archiwum materiałów wizualnych z badań nad kulturą w Polsce" to projekt, który został zrealizowany w 2014 roku $^{1}$. Jego celem było stworzenie otwartego archiwum internetowego (nazwanego przez nas Archiwum Wizualnym: www.archiwumwizualne.pl) prezentującego materiały wizualne wytworzone $\mathrm{w}$ badaniach nad kulturą w Polsce. Pomysł taki wcieliliśmy w życie kierując się przeświadczeniem, że po pierwsze, zebranie materiałów tego typu w jednym miejscu może okazać się poręcznym narzędziem diagnozowania polskiej kultury w najróżniejszych jej aspektach, po drugie, że zgromadzenie danych wizualnych uzyskanych $w$ interesujących i nowatorskich projektach może stać się pomocne w zrozumieniu tych aspektów kultury i uczestnictwa w kulturze, które wcześniej były pomijane (sytuacyjność, zmysłowość, materialność czy interakcyjność kultury). Tak stworzona baza danych wizualnych może służyć do dalszych pogłębionych badań. Przystępując do realizacji projektu byliśmy przekonani, że archiwum internetowe materiałów wizualnych pomoże spopularyzować ich wykorzystywanie w badaniach kultury.

W trakcie realizacji projektu odbyliśmy ogółem 18 spotkań z 22 osobami. Byli to kierownicy projektów badawczych lub ci członkowie zespołu, którzy odpowiadali za metodologię realizowanych badań. Założeniem leżącym u pod-

Adres do korespondencji: katarzyna.chajbos@yahoo.pl; waldekrapior@gmail.com

${ }^{1}$ Projekt powstał dzięki finansowaniu Ministerstwa Kultury i Dziedzictwa Narodowego w ramach programu Obserwatorium Kultury oraz współpracy Instytutu Socjologii UAM, Fundacji Malta oraz Fundacji Międzymiastowa. Głównymi jego realizatorami byli Katarzyna Chajbos i Waldemar Rapior. 
staw doboru projektów, które potem miały zostać włączone do internetowej bazy było wykorzystanie przez zespół projektowy materiałów wizualnych $\mathrm{w}$ badaniu i/ lub podczas jego prezentacji czy promocji. W Archiwum Wizualnym zdecydowaliśmy się umieścić niejednorodną grupę projektów, które odzwierciedlają różnice potencjałów materiałów wizualnych w badaniu kultury i społeczeństwa. Pojawiły się w tej grupie propozycje, które nazwać można na wskroś „naukowymi”, na przykład projekt „Wizualna kompetencja społeczna jako przedmiot badań współczesnej socjologii”, projekty naukowo-artystyczne, jak „Formy zamieszkiwania” czy projekty naukowo-animacyjne (np. „Etnografia/animacja/sztuka. Nierozpoznane wymiary rozwoju kulturalnego"). Założyliśmy niejako, że początkowe, „startowe” treści Archiwum powinny wyznaczać bardzo szeroki zakres projektów społeczno-kulturalnych, które mogą tu trafić w przyszłości.

Archiwum gromadzi różnorodne materiały wizualne $\mathrm{w}$ formie cyfrowej i udostępnia je niezależnym badaczom, akademikom, uczestnikom kultury, władzom publicznym, instytucjom kultury itd. Ideą przyświecającą budowie Archiwum była chęć wspierania dalszych badań oraz inspirowania użytkowników Archiwum tak, aby materiały w nim zgromadzone i wiedza o procesie badawczym, w postaci rozmów z badaczami, stanowiły punkt wyjścia do nowych projektów badawczych. Chcielibyśmy, by gromadzenie materiałów tego typu doprowadziło do stworzenia poręcznego narzędzia diagnozowania polskiej kultury. Archiwum bowiem może dawać wgląd w materialny czy przestrzenny aspekt kultury (budynki, wyposażenie instytucji, a także dzieła sztuki, przedmioty użytkowe), ale także w sferę niematerialną, poczynając od różnych form promocji kultury poprzez jej wytwarzanie na sposobach uczestniczenia w niej kończąc.

Najpierw przedstawimy różne podejścia badawcze do badań społecznych stosowane przez naszych rozmówców, a także opiszemy potencjały i funkcje materiałów wizualnych przez nich wykorzystywanych. Potem w celu lepszego zrozumienia roli współczesnego badacza społecznego poszerzymy perspektywę jej opisu o kategorię intelektualisty-praktyka. Intelektualista tradycyjnie pojmowany jest bowiem jako osoba zajmująca się ideami, a nie działaniami. W ostatniej, trzeciej części pokażemy, jaką rolę w pracy intelektualisty-praktyka może pełnić Archiwum Wizualne.

\section{FUNKCJE MATERIAŁÓW WIZUALNYCH W BADANIACH KULTURY}

W wybranych dwudziestu projektach zauważyliśmy powtarzające się kategorie użycia $\mathrm{w}$ badaniach materiałów wizualnych ${ }^{2}$ - pojawiały się one $\mathrm{w}$ ra-

\footnotetext{
2 Bardziej szczegółowo analizujemy te sposoby w raporcie umieszczonym na stronie Archiwum Wizualnego.
} 
mach trzech komponentów procesu badawczego ${ }^{3}$. Pierwszy to relacje $z$ badanymi i wstępne etapy badań: budowania więzi i komfortu badanych, a także odpowiedniego przebiegu sytuacji badawczej. Materiały wizualne były bowiem traktowane jako źródło informacji, ale także środek do jej uzyskania. Obrazy (ich oglądanie, ale także tworzenie) często okazywały się okazją do rozmowy i sposobem na nawiązywanie relacji z badanymi. Stanowiły także sposób na zainteresowanie badanych tematyką realizowanego projektu oraz znosiły bariery związane $z$ sytuacją badawczą (stres, nieufność, brak zaangażowania). Jak powiedział jeden $z$ naszych rozmówców: wokót robienia zdjęcia budowała się cata interakcja, sposób pamiętania, myślenia. Te materiaty wizualne byty bardzo ważnym narzędziem $i$ byty pretekstem do rozmowy. W opinii rozmówców ich użycie zwiększało atrakcyjność badań i tym samym ułatwiło budowanie pozytywnych relacji z badanymi. Użyteczność materiałów wizualnych podczas badań była wiązana także $z$,wymuszaniem" na badanych urefleksyjnienia swoich działań. Wykorzystanie materiałów wizualnych i technik, które temu właśnie służyły, występowało głównie $\mathrm{w}$ projektach o charakterze partycypacyjnym i animacyjnym (np. w projekcie „Tworzenie kultury”). Interesujące jest to, że niektórzy, potwierdzając refleksjotwórcze właściwości materiałów wizualnych, celowo rezygnowali z proszenia badanych o ich tworzenie, a więc fotografowanie czy robienie filmów. Tłumaczyli, że dokumentowanie rzeczywistości skutkuje przyjmowaniem niecodziennej perspektywy: Wydaje mi sie, że aparat fotograficzny sprawitby, że [badani] robia „,krok $w$ tyl" i z zewnątrz spojrza na doświadczenie, o którym opowiadaja. Kadrowanie sprawia, że badani nie tylko bardziej zastanawiają się nad utrwalaną rzeczywistością, ale także porzucają indywidualne sposoby patrzenia. Argumentując, że niejednokrotnie może się to okazać niekorzystne dla ostatecznych celów badawczych, niektórzy rozmyślnie zrezygnowali z tych technik (jak w przypadku projektu „Kompetencja wizualna”).

Drugi komponent procesu badawczego został przypisany głównej części badań, podczas której tworzy się dokumentację i buduje wspólne znaczenia między badanymi i badaczami, a także $\mathrm{w}$ grupie samych badaczy. Jeden $z$ naszych rozmówców tę dokumentacyjną funkcję materiałów wizualnych określił mianem „notatki terenowej” ${ }^{4}$, która pokazuje pewien wycinek rzeczywistości, jest narzędziem pamiętania i odtwarzania zdarzeń, emocji i relacji, które zostały na niej utrwalone. $Z$ jednej strony może służyć badaczom, którzy prowadzili badania, po to by „odświeżyć” wspomnienia, zadziałać jak wehikuł czasu i pomóc wrócić do poznanych realiów. Z drugiej strony umożliwia dostęp do badań terenowych i zaistniałych tam relacji osobom, które nie brały aktywnego udziału w ich przebiegu. Jeden z rozmówców podkreślał, że [...] techniki

\footnotetext{
${ }^{3}$ Należy zaznaczyć, że podział na wskazane trzy kategorie nie zawsze się sprawdzał: można przecież wyobrazić sobie na przykład, że dokumentacyjny potencjał materiałów wizualnych może być wykorzystywany podczas wszystkich trzech etapów badawczych.

4 Notatką tą było zdjęcie.
} 
wykraczające poza rejestrację $i$ wymianę stów pozwalaja wczuć się $w$ środowisko życia uczestników badania $i$ dostrzec rzeczy, które nie wychodza $w$ innych rodzajach analiz. Materiał wizualny może być także ułatwieniem w prowadzeniu dyskusji między badaczami na temat przebiegu badań. Korzystając ze zdjęć i notatek terenowych zapewne warto jednak pamiętać o ograniczeniach, a mianowicie o tym, że analizując zdjęcie zrobione $\mathrm{w}$ „terenie” należy myśleć także o tym, czego na nim nie ma i co było tego przyczyną. W terminologii fotograficznej powiemy, że robiąc zdjęcie „kadrujemy” rzeczywistość, gdyż podejmujemy arbitralne decyzje o istotności konkretnych elementów przestrzeni. Mogą one być podporządkowane pewnemu stylowi fotografowania (własnemu bądź kopiowanemu), ale przede wszystkim indywidualnej interpretacji rzeczywistości. Wartość materiałów wizualnych na drugim etapie procesu badawczego okazała się istotna także w kontekście konfrontowania własnych, początkowych założeń badawczych z rzeczywistością przedstawioną na obrazach. Jak powiedział jeden $\mathrm{z}$ członków zespołu badawczego:

Sądze, że materiat wizualny może petnić role bezpiecznika. [...] Mam wrażenie, że kiedy kieruje się projektem $i$ ma się silne, wzmocnione teoriami $i$ książkami zatożenia, to mimowolnie można skrzywić wnioski tak, by one zgadzały się z tymi założeniami. Zdjęcia natomiast sa dla mnie narzędziem niszczenia komfortu, poczucia, że wszystko do siebie pasuje i się ze soba skleja.

Materiały te mogą bowiem nie tylko potwierdzać nasze spostrzeżenia, ale również przeczyć wcześniejszym intuicjom i w konsekwencji zmuszać do zmiany kierunku wnioskowania $\mathrm{w}$ trakcie pisania raportu $\mathrm{z}$ badań (zostało to podkreślone na przykład w projekcie „Młodzi i media”).

Trzeci komponent badań to ich ostatni etap: prezentacja wyników. Po pierwsze, rola materiałów wizualnych może tu zostać określona jako „artystyczna” czy „estetyczna”. W takim ujęciu obrazy miały „robić wrażenie”, a zatem być źródłem innych przeżyć i reakcji niż tekst, słowo pisane. Takie zestawienie dwóch mediów: obrazu i tekstu, wskazuje na zapis jako narzędzie komunikowania treści merytorycznych, opisowych i przekazujących „niewidoczne”, zdaniem autorów, ich elementy. Rozmówcy często przeciwstawiali wartości estetyczne obrazów tym naukowym, przypisywanym tekstom pisanym ${ }^{5}$. W ich opinii zdjęcia (o tych była mowa najczęściej) miały urozmaicać odbiór treści, ale już ani nie pogłębiać jej, ani nie tworzyć nowych jej kontekstów. Oto wypowiedź, która dobrze podsumowuje to przekonanie:

Często raport jest $w$ zasadzie prezentacja, a nie raportem. Kilka wykresów, haset, dymków, krótki opis. Powiem szczerze, że jestem przeciwny takiemu rozwiazaniu. Jest to zbyt stabe wykorzystanie danych zebranych $w$ trakcie badan. Na pewno potrzebny jest zarówno materiat wizualny, jak i treść. Natomiast do robienia skrótów, do uzupetniania, do prezentacji materiat wizualny jest niezbędny.

${ }^{5}$ Należy zaznaczyć, że nie zawsze wprost, ale taka postawa była kluczowa dla ich rozumienia funkcjonalności materiałów wizualnych. 
Zapożyczając terminologię ze współczesnego marketingu, można powiedzieć, że obraz „sprzedaje tekst” poprzez wywołanie emocji czy wzbudzenie zainteresowania. Nieprzypadkowo więc nasi rozmówcy często określali obrazy jako „dobry materiał promocyjny”. Taką funkcję w kilku projektach miały pełnić na przykład fotokasty czy wystawy zdjęć, które były nie tylko bardziej atrakcyjnym niż tekst medium zainteresowania projektem, ale także narzędziem służącym do intersubiektywizacji jego rezultatów.

Po drugie, rola materiałów wizualnych na ostatnim etapie badań polega także na uwspólnianiu pewnych znaczeń, opowieści osoby piszącej o ich rezultatach. Obraz w tym przypadku ułatwia „dostrojenie się” do wizji autora tekstu — pozwala w pełni zrozumieć jego zamysł i minimalizuje niedopowiedzenia czy złą jego interpretację.

Teraz, kiedy jestem już bardziej doświadczony, bardziej niż zwykłe oddanie treści wniosków badań raport interesuje mnie jako opowieść, która jest mocno zanurzona w rzeczywistości i opowiada o tym, co jest. Zdjęcia mogtyby wzmocnić ich efekt poznawczy, sprawić, że przemawiatyby lepiej do czytelnika, pomagatyby mu wejść $w$ tę narrację.

Taka funkcja materiałów wizualnych była dostrzegana w odniesieniu do badań etnograficznych, a obraz: odpowiednie jego kadrowanie, ale również sam fakt zrobienia go w danym momencie, służył za ilustrację wspólnoty badanego i badacza. Zasadzała się ona na zainteresowaniu danym wycinkiem rzeczywistości i chęci utrwalenia go przez fotografię czy film. Należy jednak dodać, że taka technika duplikowania komunikatu wymaga odpowiednio wysokich kompetencji od fotografa, który powinien dobrze uchwycić na zdjęciu treść, do której ono się odnosi, albo (co zdecydowanie częstsze ze względu na logikę procesu badawczego, w którym wnioski zapisywane są dopiero po zebraniu wszystkich materiałów w terenie) od piszącego tekst, który powinien wziąć pod uwagę zarówno to, co przedstawia zdjęcie, ale także kontekst jego utworzenia (jak w przypadku rozumienia zdjęcia jako „notatki terenowej”).

\section{WIEDZA SPOŁECZNA I INTELEKTUALIŚCI}

Nauka przestała dziś mieć pozycję jedynego prawomocnego wytwórcy wiedzy. Wciąż jednak dominuje stereotyp, który funkcjonuje na poziomie biurokratycznym i publicznym, iż prawdziwą wiedzę mogą wytwarzać tylko naukowcy, akademie i uniwersytety. Niektórzy badacze działający $w$ ramach organizacji trzeciego sektora żalili się, że spotykali się ze sceptycyzmem zarówno ze strony urzędników, jak i obywateli, gdy ci dowiedzieli się, że nie reprezentują ośrodka akademickiego. Współcześni teoretycy i historycy nauki nie mają jednak wątpliwości - nauka jest tylko jedną z wytwórczyń prawomocnej wiedzy, obok konsorcjów badawczych, think-thanków, NGO, dziennikarzy, korporacyjnych ośrodków badawczych czy niezależnych badaczy. W tradycyjnym podejściu do wiedzy społecznej (TASK - traditional approach to knowledge) (Camic, 
Gross, Lamont 2011) wiedzę traktuje się jako ewoluujące idee: albo post factum (skupienie się na tradycji intelektualnej i ideach jakiegoś myśliciela zawartych w kanonicznych tekstach), albo jako poszukiwanie źródeł idei w zewnętrznych przyczynach (w warunkach ideologicznych, ekonomicznych, politycznych oraz klasowych i grupowych interesach). Wiedza tak rozumiana była ściśle związana ze spektakularną pozycją nauki w XX wieku i podziałami na samodzielne i obudowane grubym murem dyscypliny. Była to wręcz praktyka, jak powie Eva Barlösius (2009), zamykania klasyków w złotych klatach.

Współczesna literatura dotycząca wiedzy społecznej, wywodząca się z tradycji studiów nad nauką i technologią (STS - science and technology studies) (Latour, Woolgar 1986), za podstawowe pojęcie nie uważa „idei”, lecz „praktykę”. Wiedza jest wytwarzana poprzez konkretne działania. W takim podejściu nie zawęża się praktyk do następujących chronologicznie po sobie trzech czynności niezbędnych do produkcji idei: czytania, myślenia i pisania. Wytwarzanie wiedzy jest praktyką cielesną, odbywającą się w czasie, $w$ którym istotną rolę pełnią relacje zawiązywane między heterogenicznymi elementami umożliwiającymi produkcję wiedzy: materią (laboratoria, biblioteki, bazy JASTOR itd.), ekonomią, kulturą, tym, co społeczne. Wszystkie działania są lokalne, a niektóre $z$ nich łączą się $z$ innymi działaniami i powtarzają $w$ wielu miejscach, stając się działaniami translokalnymi (Czerniawska 2010, s. 43). Takie podejście do wiedzy społecznej wyostrza spojrzenie na inne rodzaje wiedzy niż wiedza naukowa. Daje możliwość efektywnego zajęcia się praktykami, a nie ideami. Wreszcie kieruje oko badacza na interpretację działań, a nie ewoluujących idei. Przyjęliśmy to podejście — oraz podejście amerykańskiego pragmatyzmu — budując Archiwum Wizualne, a także pisząc podsumowanie z tego "placu budowy”.

Pragmatyczne podejście do wiedzy społecznej zwraca uwagę na dążenie do wiedzy zorientowanej na samorozumienie (Baert, Carreira da Silva 2013). Pragmatycy uważają, że nie mamy niezapośredniczonego dostępu do świata zewnętrznego. Wiedza nie tyle ma dostarczać informacji o świecie, ile o nas samych — o tym, jak utrwalają się nasze przekonania, na jakim zbiorze założeń opiera się nasza wiedza o świecie, jak rzutujemy kategorie i pojęcia, którymi się posługujemy, na sposoby myślenia innych ludzi, przeszłość, przyszłość czy inne regiony świata. Wiedza autoreferencyjna czyni nasz system przekonań wrażliwym na nowe doświadczenia i podważa to, co uznawaliśmy za oczywiste. Tego typu wiedza jest bezużyteczna, jeśli zamkniemy ją w złotej klatce hermetycznych teorii albo za murami akademii. Klasą społeczną, która tradycyjnie przekraczała granice bibliotek i laboratoriów, byli intelektualiści. Stanowili oni odzwierciedlenie zamiłowania XIX wieku do obiektywizmu, wytwarzania informacji oraz ich cyrkulacji, odbioru w przestrzeni publicznej i powszechnej do nich dostępności ${ }^{6}$.

${ }^{6}$ Wiek XIX uczynił z wiedzy coś, co jest ważne publicznie. Główne nurty ideologiczne tego stulecia (pozytywizm, historyzm, ewolucjonizm, realizm) motywowały i wspierały dążenia do 
Historyk Tony Judt twierdzi, że intelektualiści jako klasa społeczna odeszli w niepamięć w latach sześćdziesiątych XX wieku oraz wskazuje na cztery grupy, które zastąpiły intelektualistę: teoretycy polityczni produkujący ideologie dla partii politycznych albo korporacji; think-tanki — wyspecjalizowani w wąskiej dziedzinie eksperci; dziennikarze wojenni i śledczy ujawniający afery polityczne i ekonomiczne, wykorzystywanie ludzi i gwałcenie ich godności oraz łamanie praw człowieka (w nieco innym charakterze moglibyśmy dodać tu także takie NGO jak Human Rights Watch); akademicy, których rolą jest poszukiwanie prawdy, czyli przekonującej narracji o rzeczywistości - ich publicznością są studenci, a wypowiadając się na przykład w radiu, telewizji, internecie rozszerzają ją o wszystkich tych, którzy chcą ich słuchać. Judt podsumowuje rolę akademików jako intelektualistów parafrazą powiedzenia klasyka: „intelektualiści tylko zmieniali świat, rzecz w tym, aby go prawidłowo interpretować". Podsuwa nam myśl, że intelektualiści nie wymarli, ale w pełnieniu ich tradycyjnej roli zostali zastąpieni przez inne grupy (Judt 2007).

Według socjologa Patrica Baerta (Baert, Booth 2012), intelektualiści nie są tylko wspomnieniem - ich dziewiętnastowieczne ideały wciąż mogą być realizowane przez komentowanie spraw publicznych (cokolwiek to dziś znaczy), a miejscem, w którym miałoby się to dziś odbywać, jest blogosfera. Internet bowiem niweluje mediację stacji telewizyjnych lub radiowych, blogosfera indywidualizuje odbiór, skraca dystans i tworzy bardziej intymną relację między intelektualistą a jego słuchaczem/czytelnikiem. W perspektywie pragmatycznej ważniejsze od motywacji, intencji albo celów, jakie stawiają sobie różni ludzie lub instytucje, są efekty, jakie wywołują publiczne interwencje. Blogosfera umożliwia dostrzeżenie tych efektów dzięki śledzeniu komentarzy albo rozpowszechnianiu treści wypowiedzi na różnych platformach internetowych. Intelektualista przestaje polegać na wytworzonej i podtrzymywanej przez danego nadawcę publiczności i sam wytwarza oraz podtrzymuje swoją publiczność ${ }^{7}$. Craig Calhoun (@craigjcalhoun) zamieszczał na Tweeterze linki do artykułów dziennikarskich i akademickich. W ten sposób komentował, ale też tworzył miniarchiwum tekstów źródłowych o jakimś problemie społecznym.

Intelektualista „uniwersalny”, który wypowiada się autorytarnie i — jak mówił Sartre - „miesza się do nie swoich spraw”, wydaje się dziś figurą naiwną: „Nie ma dziś miejsca dla Hegla czy Marksa, Comte'a czy Spencera” twierdzi Jerzy Szacki (1991, s. 401). Ze względu na rosnącą złożoność świata współczesny intelektualista jest raczej pomocnikiem lub mediatorem. Alfabe-

akumulacji wiedzy i jej uniwersalizacji. Za wiedzę nie uznawano normatywnie zorientowanych refleksji politycznych, religijnych albo społecznych, lecz przybliżenie do obiektywizmu. Samoopisanie XIX wieku polegało na rejestracji faktów i odnajdowaniu kryjących się za nimi wzorów i prawidłowości (Osterhammel 2013).

7 Nie jest to oczywiście przypadek czysty. Nie licząc mediacji technologii i materialnych przyrządów, sieć internetowa jest sprywatyzowana. Wyszukiwarki, blogi, media społecznościowe często pozostają w rękach wielkich graczy (jak Google, Amazon). 
tyzacja, rozwój edukacji, rozpowszechnienie teorii społecznych powodują, że ludzie nie tylko mają większą wiedzę i świadomość o procesach społecznych i politycznych, ale także są bardziej krytyczni w stosunku do osób dyktujących to, jak powinno być. Wiarygodniejszy dziś jest intelektualista „konkretny”, o którym pisał Michel Foucault, czyli specjalista, który swoje miejsce zawdzięcza temu, iż „W jakiejś dziedzinie jest tak dobry, że niepodobna się bez niego obejść" (zob. Szacki 1991, s. 401).

Za początek dziejów zaangażowanego politycznie intelektualisty uznaje się reakcję, zarówno zwolenników, jak i przeciwników, na aferę Dreyfusa ${ }^{8}$. Podobnie jak w przypadku „tradycyjnej” roli intelektualisty jako wytwórcy (albo współtwórcy) „afery”, „sprawy” albo „problemu publicznego”, działania badaczy, z którymi rozmawialiśmy, także mieszczą się w perspektywie fabrykowania, czyli konstruowania problemu społecznego. Odbywało się to przez, po pierwsze, przeprowadzenie rzetelnych, w duchu wartości akademickich, badań i interpretację materiału badawczego wygenerowanego w ramach danego projektu. Kierowanie się regułami nauki nie prowadziło do zamknięcia się w ścianach laboratoriów lub bibliotek. Drugim elementem fabrykowania problemu społecznego było tworzenie jasnego komunikatu za pomocą materiałów wizualnych oraz dotarcie $z$ tym komunikatem do nie tyle szerokiej, ile celowej publiczności - wybranych decydentów, lokalnych ośrodków kultury, grup (animatorów, edukatorów, urzędników, przedstawicieli instytucji zajmujących się daną sprawą itd.) albo obywateli, którzy byliby zainteresowani rezultatami badań. Badacza, który działa na pograniczu kultury i polityki, nazwaliśmy „intelektualistą-praktykiem" ${ }^{\text {. }}$

\section{INTELEKTUALISTA-PRAKTYK}

Kim jest intelektualista-praktyk? Z pewnością nie jest nim intelektualista w stylu Sartre'a, czyli ktoś, dla kogo abstrakcja, a nie fakty, jest tym, co praw-

${ }^{8}$ Przypomnimy: francuski oficer żydowskiego pochodzenia został niesłusznie oskarżony o zdradę. Dzień po słynnym liście J’accuse...! (Oskarżam!) Emila Zoli ze stycznia 1889 roku dziennik „L'Aurore” opublikował Manifest intelektualistów: „My, niżej podpisani, protestujemy przeciwko pogwałceniu procedury sądowej oraz przeciwko aurze tajemniczości otaczającej sprawę Esterhazyego i trwamy przy żądaniu rewizji" (cyt. za Lukes 2012, s. 381). Ich oponenci, oskarżyciele Dreyfusa, powoływali się na „prawdę wyższego rzędu”: na to, że „Francja jest na pierwszym miejscu, armii nie wolno znieważać, a cele wspólne są ważniejsze niż jednostkowy interes" (Judt, Snyder 2013). Durkheim, dobry przyjaciel przywódcy partii socjalistycznej Jeana Jaurèsa, w eseju Indywidualizm $i$ intelektualiści potępił głoszoną przez nich ideę, że nigdy nie należy kwestionować wyroków Kościoła lub wojska ze względu na wagę tego, co dzisiaj nazywamy bezpieczeństwem narodowym (zob. Lukes 2012, s. 14-30).

${ }^{9}$ Analizując materiał zgromadzony podczas budowania Archiwum Wizualnego nie szukaliśmy napięć (hierarchia-równość, generalizacja-ekspertyza, pasja-dystans, indywidualność-kolektywność) (Baert, Booth 2012), które charakteryzują intelektualistę, lecz postąpiliśmy odwrotnie: czytając wywiady i przeglądając zgromadzone materiały, ustalaliśmy, co robią z materiałem wizualnym badacze, jak z niego korzystają, jakie podejmują działania. 
dziwie istnieje (zob. Judt 2013). Badacze, z którymi rozmawialiśmy, kierowali się bowiem akademicką wartością obiektywizmu. Czy jest to zatem intelektualista $\mathrm{w}$ roli krytyka kultury? Też nie. Nasi rozmówcy nie starają się być „obrońcami uciśnionych”. Oddolna inicjatywa obywatelska, choć często pieczołowicie opisywana, popierana i wspierana, nie była przez nich uznawana za aksjomat: Paradoksem jest to, iż najmniej obywatelscy, najmniej skłonni do wspótpracy sa nie administratorzy albo urzędnicy, tylko obywatele — powiedział jeden z badaczy. Sfera administracyjna nie jest według nich monolitem, molochem lub lewiatanem, godnym demaskacji i krytyki. Dostrzegali problemy instytucji kultury i innych instytucji publicznych, a widząc je, nie przyjmowali postawy pełnej podejrzeń: mówili raczej o konkretnych przejawach nadużyć, nie generalizując. Na przykład wskazywali na paradoksalną, gdyż obusieczną, wagę tzw. czynnika ludzkiego (por. Krajewski 2014). Z jednej strony czynnik ludzki prowadzi do „rozsypania systemu”:

Rzecz się rozsypuje w najprostszym elemencie. Dziewczyna, z która kiedyś wspótpracowaliśmy, opowiadała, jak jako studentka trafita na staż do Urzędu Marszatkowskiego. Staż polegat na tym, że studenci pomagali w procesie składania, odbierania, rozsytania wniosków o dotacje i przy kawie czytali te wnioski, otwierali teczki, przesytali, kumpel kumplowi, kserowali, zabierali.

Pracownik administracji publicznej, urzędnik, badacz czy stażysta, jak sugeruje powyższy cytat, powinien kierować się jasnymi procedurami, a nie swoimi własnymi interesami, gustem, sympatią lub antypatią. $Z$ drugiej strony jednak — „czynnik ludzki” pojmowany był często jako jedyny czynnik prowadzący do efektywnych zmian instytucjonalnych: Myśle, że pewne rzeczy można po prostu odgórnie wymuszać - powiedział jeden z rozmówców. Co przyczynia się do tego, iż system może wymusić tzw. dobre praktyki? Czytając zamieszczone w Archiwum Wizualnym wywiady nie mamy wątpliwości — „mądrzy i odważni ludzie”. Nasi rozmówcy zwracali uwagę na to, iż do naprawienia niesprawnie funkcjonujących instytucji kultury potrzebny jest „korzystny układ personalny”:

Myśle że w polskich warunkach o takim powodzeniu zwykle decyduje korzystny układ personalny. Trudno mówić tutaj o jakiejś regule, ale często tak właśnie jest. Biorac pod uwage regionalne reformy instytucji kultury, to pierwszy przeprowadzit ja krakowski MIK [Małopolski Instytut Kultury], który teraz uznawany jest za ikonę tego, jak przerobić wojewódzkiego molocha $w$ nowoczesny, regionalny Instytut Kultury. $W$ tym przypadku decyzje podejmowali madrzy i odważni ludzie. Bez tak korzystnej konstelacji personalnej dokonanie takich reform nie bytoby możliwe. Podobne, ale zdecydowanie już nie tak glębokie, zmiany udaja się też $w$ innych miejscach. Potrzeba jednak zgody pewnej grupy osób, by tworzyć tak modelowe i systemowe rozwiązania jak te w Krakowie.

$Z$ rozmów $z$ badaczami wynika, iż do zmian instytucjonalnych $w$ głównej mierze przyczyniają się ludzie z pasją lub kierujący się ideałem, a jednocześnie zdeterminowani w swych działaniach, a nie tylko zarząd instytucji, przywódcy polityczni albo jasne procedury. Tacy ludzie okazują też chęć współpracy z innymi. Aktywne społeczeństwo nie jest ideałem, a czynni i zaradni obywatele nie 
są wzorem samym w sobie. Badacze kultury właśnie we współpracy, zarówno z obywatelami, jak i urzędnikami oraz innymi badaczami, widzieli swoją rolę jako osób podejmujących ważne społecznie tematy.

Podczas lektury zebranych wypowiedzi znajdziemy w nich potrzebę profesjonalizacji i dyscypliny: ważne okazywały się poprawnie sformułowane instrukcje fotografowania, ścisłe dotrzymywanie terminów, konsekwentne podążanie za celami badawczymi, a także kompetencje wyniesione $z$ terenu. Badacze, z którymi rozmawialiśmy, nie byli jednak tylko, mówiąc słowami C. Wrighta Millsa (2008), technikami. Kategoria ta nie odpowiada charakterystyce naszych rozmówców, ponieważ technik nie jest zainteresowany kwestią szerokiego udostępnia wiedzy. Nasi rozmówcy zaś spoglądają na raport badawczy zarówno z perspektywy poznawczej (jaka wiedza w nim się znajduje), jak i estetycznej (jak ta wiedza ma zostać zaprezentowana) oraz z punktu widzenia uczestniczenia $\mathrm{w}$ życiu publicznym (jak dotrzeć $\mathrm{z}$ informacją do różnych publiczności). Z jednej strony znajdowało to wyraz w chęci pokazania atrakcyjnych obrazów, to jest dobrze wykadrowanych zdjęć albo zdjęć dobitnie obrazujących pewien problem, z drugiej - dostosowania przekazu do konkretnego odbiorcy. Charakterystyczna jest dla badaczy kultury wielokanałowość udostępniania wiedzy: korzystanie z filmu, zdjęć, pisma, ulotek, plakatów, YouTube’a, Facebooka, blogów, wystąpień konferencyjnych, sympozjów, spotkań. Ulotki rozsyła się do ośrodków, które mogłyby być zainteresowane określoną informacją, ale też do takich, w których bywają osoby zaciekawione danym tematem.

Chcąc dobrze scharakteryzować model intelektualisty-praktyka, który przypisaliśmy badanym, należy dodać, że ich działania prowadzą do „odrzeczowienia” badań kultury. Dla większej części badaczy projekt badawczy — „obiekt” albo „rzecz” na papierze, w rubrykach wniosku grantowego - był częścią szerszego zamierzenia realizowanego zarówno przed jego zakończeniem, jak i później. Szersze przedsięwzięcie mogło zaistnieć dzięki „determinacji w działaniu”, czyli niekiedy finansowaniu czegoś (np. plakatów) z własnej kieszeni, poświęcaniu czasu wolnego na dotarcie do jakichś miejsc, do jakichś ludzi, a nade wszystko: ciekawości. Bywało, że możliwość zdobycia grantu mobilizowała niektórych badaczy — dzięki temu w ogóle zainteresowali się jakimś tematem. Jednak po zakończeniu finansowania często nie porzucali rozbudzonego dzięki grantowi zaciekawienia danym problemem, ale szukali sposobności do jego kontynuacji. Projekt badawczy był elementem w układance złożonej $\mathrm{w}$ wielu działań, grantów, powiązań i form współpracy. Badanie kultury jest, mówiąc metaforycznie, puzzlem powiązanym z innymi działaniami, lecz ma specyficzne kontury wyznaczone przez kryteria poznawcze. Teorie społeczne dziś zajmują pozycję intelektualnego pośrednika i katalizatora interdyscyplinarnych debat (Baert, Carreira da Silva 2013), ale najlepszymi kryteriami poznawczymi dla naszych rozmówców pozostają fakty i kryterium prawdy. Ustalenia faktyczne są czymś innym niż promocja albo udostępnienie wiedzy określonym społecznościom, ale badacze łączyli obie perspektywy. Zwracali jednak uwagę, 
że w swych badaniach bądź, mówiąc szerzej, przedsięwzięciach nie zawsze mieli dosyć czasu, pieniędzy, energii na realizację ich obu ${ }^{10}$.

\section{SPOWOLNIENIE, CZYLI FABRYKOWANIE PROBLEMU SPOŁECZNEGO}

Badacze, $\mathrm{z}$ którymi rozmawialiśmy, dążą $\mathrm{w}$ swych badaniach do zachowania bezstronności, lecz niekoniecznie neutralności. Z takim podejściem łączy się przekonane Leszka Kołakowskiego (2011, s. 100-118) o potrzebie rezygnacji z neutralności wówczas, gdy trzymanie się z boku, świadome zachowywanie się $\mathrm{w}$ taki sposób, aby nie wpłynąć na rezultat konfliktu, jest zgubne. Często zajmują stronę w konflikcie, opowiadają się za jakimś instytucjonalnym rozwiązaniem. Nie robią tego jednak w sposób spektakularny. Czasami sygnalizują tylko swoją niezgodę na jakieś postępowanie urzędników, przedstawicieli kultury albo obywateli. Słychać w ich wypowiedziach i widać w ich działaniach potrzebę zabierania głosu, wskazania takiej polityki kulturalnej albo formy badań kultury, która propagowałaby wartości przez nich popierane. Niekiedy dają temu wyraz przez dobór narzędzi badawczych i odpowiednie ich wykorzystanie. Jak powiedział jeden $z$ naszych rozmówców: Najpierw powinniśmy myśleć, co możemy razem $z$ ludźmi zrobić, a dopiero potem sięgać po narzędzie. Czy jest to uwaga techniczna? Tak. Czy jest to uwaga nawiązująca do uczestniczenia w życiu publicznym? Również. W perspektywie normatywnej uwaga ta wymaga, aby badacz wiedział, z kim chce zrobić badania, a co ważniejsze, że chce zrobić je razem $z$ badanymi. Badacz decyduje się wejść do jakieś społeczności, co pociąga za sobą szereg konsekwencji i kolejnych pytań, dotyczących na przykład formy i sposobów prezentacji materiału badawczego, ochrony prywatności uczestników projektu badawczego, roli badania w społeczności lokalnej albo w poszerzeniu definicji animacji i edukacji kulturowej itd.

Wszyscy nasi rozmówcy zdecydowali się na włączenie do swoich badań materiałów wizualnych i byli zgodni co do stwierdzenia, że spowalniały one cały proces badawczy. Sformułowanie problemu społecznego w przypadku naszych rozmówców nie zaczyna się, jak chciałby tradycyjnie rozumiany intelektualista, od argumentu albo teorii lub debaty intelektualnej, lecz od działań i pracy $z$ materiałami wizualnymi lub $z$ narzędziami do ich wytwarzania. Materiały wizualne powodują spowolnienie, gdyż, po pierwsze, przeprowadzenie rzetelnych badań z ich wykorzystaniem wymaga osobnego planu, odpowiedniej ilości czasu, nastawienia angażującego w interakcję z badanym oraz nastawienia dystansującego od tej interakcji, oddzielnego zespołu badawczego, który skupi się tylko na badaniu:

10 Emocją często pojawiającą się w wywiadach jest żal. Niektóre zakładane działania albo pomysły nie zostały bowiem zrealizowane zgodnie z zamierzeniem lub nie wzięto ich $\mathrm{w}$ ogóle pod uwagę, także ze względu na brak doświadczenia (np. wiedzy o tym, jak można do różnych celów wykorzystać materiał wizualny). Jeśli projekt był kontynuowany, to badacze zwykle nie popełniali tych samych błędów, unikali też pułapek, które pojawiły się we wcześniejszych badaniach. 
Zawsze mieliśmy ideę, że po prostu dobrze bytoby zrobić jakieś ciekawe badania na Kujawach. Zazwyczaj, oprócz warsztatów, koncertów, zabawy, wystaw, publikacji, próbowaliśmy wtłoczyć malusieńki komponent badawczy. Efekt byt taki, że zajmowaliśmy sie głównie sprawami organizacyjnymi $i$ procesem edukacyjnym, a badania schodzity na drugi plan. Potrzebowaliśmy specjalistów $i$ osób przygotowanych do badań, którzy po prostu pójda $w$ teren, a żeby mieć takich specjalistów, musieliśmy mieć na to środki.

Po drugie, w obrębie procesu badawczego materiał wizualny spowalnia badania na podstawowym poziomie: przygotowania zgody na fotografowanie, zdobycia umiejętności posługiwania się sprzętem, a czasem doboru odpowiedniego sprzętu i jego aranżacji (np. w przypadku wideospacerów należy tak zainstalować mikrofon, aby rejestrował dźwięk na wysokim poziomie, a jednocześnie aby nie przeszkadzał informatorowi w spacerowaniu i swobodnym snuciu opowieści). Źródłem spowolnienia jest też obecność urządzenia (aparatu fotograficznego) albo przedmiotu (papierowe zdjęcie) w interakcji międzyludzkiej (np. w sytuacjach gdy badacze zobligowani byli do wytłumaczenia się, a więc też zagajenia rozmowy, dlaczego fotografują lub gdy badani na widok aparatu fotograficznego reagowali zakłopotaniem czy ogólną podejrzliwością podczas trwania badań). Obecność takich elementów pomaga też nawiązać relację z badanym (np. poprzez rozmowę na temat zdjęć albo ich przeglądanie $z$ badanymi). Na poziomie analizy materiały wizualne wydłużają badanie chociażby ze względu na proces anonimizacji danych, w przypadku materiałów wizualnych dość kłopotliwy. Analiza wymaga cierpliwości, żmudnego i czasochłonnego przeglądania surowych danych.

Dla badaczy, z którymi rozmawialiśmy, bardzo istotna była możliwość wizualizacji wniosków badawczych, gdyż pozwalała ona na szybkie i skuteczne przedstawienie pewnych problemów. Twierdzili, że zarówno oni, jak i decydenci (lub inne grupy) operują swoimi kodami, które są w dużej mierze wzajemnie „nieprzekładalne”. Opierając się na słowach badanych można stwierdzić, że decydenci operują prostymi, krótkimi i ogólnymi kodami, kierują się logiką prostoty. Chcą, aby złożone sytuacje sprowadzić do „liczb i wykresów”: Wiedzieliśmy, że bardzo trudno będzie nam pokazać to, co przemawia do decydentów, czyli liczby $i$ wykresy $i$ że nie będzie nam łatwo im wyjaśnić, dlaczego wtaśnie tak ten projekt wykonywaliśmy. Większość natomiast dostrzega złożoność sytuacji. W przeciwieństwie do liczb i wykresów, jak powiedział jeden z naszych rozmówców: Jezyk obrazowy ma zupetnie inny charakter. Powinien zaskakiwać nas tym, że jeśli nas na to stać, mamy możliwość innego sposobu spojrzenia. Potęga materiałów wizualnych nie tkwi w tym, iż są prostą informacją, lecz w możliwościach wzbudzenia emocji, uobecnieniu ludzi, przedmiotów i miejsc, we wspieraniu pamięci. Materiały wizualne zagęszczają pojęcia, słowa-klucze, którymi posługujemy się w debatach publicznych. Niektóre z tych pojęć z czasem stają się na przykład kryteriami finansowania projektów badawczych, animacyjnych, edukacyjnych czy artystycznych. Naiwnością byłoby jednak myśleć, że samo zastąpienie liczb 
zdjęciami rozwiąże napięcie prostota-złożoność. Wiele „najfajniejszych” — jak mówią nasi rozmówcy - efektów badawczych, zwłaszcza animacyjnych i opartych na współpracy, jest bardzo trudnych do sparametryzowania i przedstawienia w oczekiwanej przez dysydentów, bezstronnej i prostej formie. Badacze, pochylając się nad prywatnymi, jednostkowymi światami, dążą do stworzenia problemów publicznych, które byłyby przedmiotem dyskusji, a jednocześnie nie prowadziły do zubożenia tych światów.

Nasi rozmówcy nie mówili o spowolnieniu badań w kategoriach zatoru, balastu, przeszkody. Spowolnienie można traktować w kategoriach negatywnych przez pryzmat funkcjonalności systemu grantowego (wspominano o wymogach tego systemu, między innymi o pisaniu sprawozdań, potrzebie zamknięcia badań do końca roku kalendarzowego, ale też o braku elastyczności tego systemu na pojawiające się sytuacje itd.). Aby przyspieszyć badania, ze względu na wymogi systemów grantowych, pomijano po prostu materiał wizualny albo redukowano jego potencjał poznawczy do zadań marketingowych. Mówiąc inaczej, rezygnowano z funkcji wyzwalacza wyobraźni czy pretekstu do rozmowy $z$ badanym na rzecz funkcji promocyjnej lub ilustracji gotowych wniosków wyciągniętych $z$ innych danych: wywiadów, ankiet, analizy treści. Nasi rozmówcy nie mieli jednak wątpliwości, że warto poświęcić więcej czasu i pieniędzy na spowolnienie i wydłużenie procesu badawczego. Wyrażali chęć powrotu do przeanalizowanych materiałów wizualnych, gdyż post factum dostrzegali ich walory, które wcześniej przyspieszając badania przeoczyli: Chciatabym, żeby nadarzyła się okazja, żebym mogła do tych materiałów wrócić ponownie $i$ napisać follow up, czyli raport $z$ perspektywy czasu - tak jak teraz widze problem uczestnictwa $w$ kulturze. W kategoriach jednostkowych spowolnienie było widziane jako konieczne dla rozwiązania dwóch problemów, które powracały we wszystkich rozmowach: jak w przedsięwzięciu badawczym połączyć dwa interesy (interes akademicki, czyli rzetelne badania, oraz interes publiczny, czyli rzetelne docieranie $z$ badaniami do różnych publiczności).

\section{ARCHIWUM WIZUALNE A ROLA INTELEKTUALISTY-PRAKTYKA}

Kiedy przeanalizowaliśmy wywiady z naszymi rozmówcami — realizatorami różnych projektów, które trafiły do archiwalnego zbioru — i zaobserwowaliśmy wyłaniającą się z nich figurę „praktyka”, stało się dla nas jasne, że Archiwum Wizualne zostało stworzone w dużej mierze dla tych, którzy odpowiadają temu profilowi badacza. Doszliśmy do wniosku, że możliwości Archiwum ułatwiają mu codzienną pracę, a jego treści i struktura odpowiadają jego kompetencjom i sposobowi analizowania materiału badawczego ${ }^{11}$.

11 Chodzi nam tutaj o umiejętność analizy na podstawie różnych źródeł — materiałów wizualnych, narracji, słowa pisanego, ale również o odpowiedni poziom doświadczenia pozwalający na formułowanie uzasadnionych wniosków. 
Rozpocznijmy od tych funkcji Archiwum, z których mógłby skorzystać opisywany praktyk. Przede wszystkim może ono służyć jako inspiracja badawcza oraz przegląd doświadczeń i ich rezultatów pochodzących $z$ różnorodnych projektów społeczno-kulturalnych. Zamieszczone w Archiwum wywiady oraz dołączone do nich materiały i pliki metodologiczne dają bowiem dość szczegółowy obraz konkretnych projektów, który z jednej strony ma potencjał twórczy: ożywia wyobraźnię i pomaga w konstruowaniu własnych projektów badawczych. Z drugiej strony - wspomniane treści są wglądem w praktykę innych badaczy. Czytanie rozmów pod kątem konkretnych informacji dotyczących konstruowania badania czy doświadczeń badawczych ${ }^{12}$ daje szansę na uzyskanie odpowiedzi na pytania dręczące wielu badaczy społecznych. Istotne jest, by pisać o tym właśnie w kontekście figury „intelektualisty praktyka", dlatego że niezwykle ważna wydaje się dla niego wspólpraca, rozumiana jako działanie $\mathrm{w}$ ramach wspólnego celu, ale także sama jej chęć - postawa otwartości i wola tworzenia wspólnych rozwiązań ${ }^{13}$. Założeniem stojącym za powstaniem Archiwum Wizualnego była potrzeba stworzenia miejsca wymiany doświadczeń praktyków i badaczy społecznych, a zatem wirtualnej platformy współpracy. Nie jest to jednak narzędzie komunikacyjne, jako takie służyć będzie raczej portal społecznościowy czy forum internetowe, lecz miejsce dla gotowych, zrealizowanych projektów uzupełnionych opowieścią o procesie ich realizacji z przydatnymi załącznikami metodologicznymi. Tak rozumiane archiwum $-\mathrm{z}$ możliwością wymiany czy współpracy - przestaje być jedynie zbiorem treści czy bankiem konkretnych danych, a więc odbiciem przeszłości: tego, co zrobione i zakończone, a staje się zasobem wychodzącym $\mathrm{w}$ przyszłość. Zgodnie $\mathrm{z}$ koncepcją Borisa Groysa (2010), dokumentowanie często wiąże się z reprodukcją konkretnych pomysłów czy rozwiązań. Archiwum rozpatrywane pod kątem jego funkcji przydatnych dla „intelektualisty-praktyka” ma, po pierwsze, potencjał oddziaływania na przyszłość w rozumieniu zaproponowanym przez Groysa, a zatem $\mathrm{w}$ postaci powielania rozwiązań opisanych i cenionych przez badaczy. Po drugie, może prowokować do budowania nowych projektów badawczych, nie kopiujących wprost zamieszczonych w Archiwum pomysłów, ale raczej takich, które są ich syntezą, produktem powstałym na bazie interpretacji treści tam się znajdujących. Materialne treści Archiwum mogą więc zostać przekształcone $\mathrm{w}$ niematerialną formę działania - w tym kontekście

\footnotetext{
12 Archiwum daje też możliwość wyszukiwania konkretnych treści, na przykład związanych z kategorią „metodologia” czy „prowadzenie badań” (http://archiwumwizualne.pl/wyszukaj).

13 Nasi rozmówcy wracali do kategorii współpracy zarówno opisując własne projekty badawcze i konieczność jej zachowania w obrębie zespołu projektowego, jak i w szerszym kontekście społecznym: instytucji publicznych, obywateli, uniwersytetów. Wskazywali, że charakterystyczne jest, iż różni aktorzy społeczni funkcjonują w oddzielnych, wyspecjalizowanych światach, i podkreślali, jak bardzo istotne jest połączenie tych światów w formie współpracy.
} 
Archiwum rozumiane może być zatem bardziej jako proces niż skończony produkt ${ }^{14}$.

Archiwum Wizualne nie jest formą podobną do Google Earth / Google Maps, które zostały opisane przez Łukasza Zarembę (2011, s. 93) jako rodzaj archiwum, które „można przemierzać i penetrować” i które stanowi zbiór obrazów przypominający krajobraz. W przypadku Archiwum Wizualnego treści a więc zbiory materiałów wizualnych i opowieści o projektach — po pierwsze, są ze sobą nierozerwalnie połączone i wymagają wspólnego interpretowania, a po drugie, analiza każdego $z$ nich $z$ osobna musi być oparta na umiejętności sytuowania treści w odpowiednim kontekście (materiały wizualne) lub doświadczeniu (wywiady z kierownikami projektów). Analiza zarchiwizowanych treści przez łączenie elementów w przypadku Archiwum Wizualnego jest związana $z$ relacją obraz-słowo i konsekwencjami, które $z$ tej relacji wynikają. Z rozmów przeprowadzonych z kierownikami projektów jasno wynika, że większość z badaczy jest przekonana o konieczności komentowania zdjęć i innych materiałów wizualnych słowem pisanym. W ich przekonaniu za obrazami stoi niejednoznaczność, a pokazanie kilku zdjęć nie pozwala odbiorcy zrozumieć jakiegoś zjawiska. Potrzebny jest szerszy kontekst. Być może dlatego często zdarzało się, że badacze robili wiele zdjęć jakiegoś obiektu, tak aby widoczny był zarówno jego detal, jak i szerszy plan - usytuowanie tego obiektu w otoczeniu. Zdjęcia z jednej strony tworzą, wraz z opowieścią słowną, kontekst jakiegoś problemu albo zdarzenia, a $z$ drugiej, jak powiedział jeden $z$ badanych: sa narzędziem niszczenia komfortu: poczucia, że wszystko do siebie pasuje i się ze soba skleja. Wynika z tego, że obrazy mogą być częścią procesu wnioskowania i pełnią nie tylko rolę ilustracji dla słów. Jeśli chcemy odnieść swoje twierdzenia do obiektywnego świata, jak mawiał Robert B. Brandom (2012), musimy przyjąć odpowiedzialność za usunięcie niekompatybilności i niespójności w naszym wnioskowaniu. Zdjęcia kontrolują proces wnioskowania i wymuszają na analityku dokonanie korekty, jeśli to, co widać, nie zgadza się z tym, co chce powiedzieć.

Proces analizy materiałów w Archiwum Wizualnym musi być zatem oparty na świadomym łączeniu patrzenia i interpretowania materiałów wizualnych $\mathrm{z}$ opowieściami o projektach, $\mathrm{w}$ ramach których one powstały. Tylko $\mathrm{w}$ ten sposób otrzymamy bowiem pełny „obraz” treści - wsparty przez wyjaśnienia okoliczności zbierania i tworzenia tych materiałów, intencje ich autorów, sposób ich wykorzystania $\mathrm{w}$ formułowaniu wniosków $\mathrm{z}$ danego projektu badawczego. Taki sposób analizy zawiera wszystkie trzy elementy społecznego zakorzenienia materiałów wizualnych opisane przez Arjuna Appaduraia (1986) (obejmuje kontekst pierwotnego wytworzenia, dalsze losy zdjęć, a także sposób

14 Takiemu charakterowi Archiwum Wizualnego sprzyja funkcja dodawania własnych projektów badawczych. 
ich przechowywania) i może być porównany także z socjologiczną koncepcją patrzenia „za fotografię”, zarysowaną przez Rafała Drozdowskiego i Marka Krajewskiego (2010).

\section{BIBLIOGRAFIA}

Appadurai Arjun (red.), 1986, The Social Life of Things: Commodities in Cultural Perspective, Cambridge University Press, New York.

Barlösius Eva, 2009, „Klasycy w złotych klatkach”. Przyczynek do socjologii klasyków, w: Aleksander Manterys, Janusz Mucha (red.), Nowe perspektywy teorii socjologicznej, tłum. Grzegorz Sowiński, Nomos, Kraków.

Baert Patrick, Booth Josh, 2012, Tensions within the Public Intellectual: Political Interventions from Dreyfus to the New Social Media, „International Journal of Politics, Culture, and Society”, t. 25, s. 111-126.

Baert Patrick, Carreira da Silva Filipe, 2013, Teorie społeczne w XX wieku i dzisiaj, tłum. Stanisław Burdziej, Nomos, Kraków.

Brandom Robert B., 2012, Między mówieniem a działaniem. W stronę analitycznego pragmatyzmu, tłum. Marcin Gokieli, Wydawnictwo Naukowe PWN, Warszawa.

Camic Charles, Gross Neil, Lamont Michèle (red.), 2011, Social Knowledge in the Making, University of Chicago Press, Chicago.

Czerniawska Barbara, 2010, Trochę inna teoria organizacji. Organizowanie jako konstrukcja sieci działań, Poltext, Warszawa.

Drozdowski Rafał, Krajewski Marek, 2010, Za fotografię! W stronę radykalnego programu socjologii wizualnej, Fundacja Bęc Zmiana, Warszawa.

Groys Boris, 2010, The Loneliness of the Project, w: Boris Groys (red.), Going Public, E-flux Journal Books, Sternberg Press, New York.

Judt Tony, 2007, Disturbing the Peace Intellectuals and Universities in an Illiberal Age, wystapienie na konferencji (http://frontrow.bc.edu/ [30.05.2015]).

Judt Tony, 2013, Historia niedokończona. Francuscy intelektualiści 1944-1956, tłum. Paweł Marczewski, Wydawnictwo Krytyki Politycznej, Warszawa.

Judt Tony, Snyder Timothy, 2013, Rozważania o XX wieku, tłum. Paweł Marczewski, Rebis, Poznań.

Kołakowski Leszek, 2011, Neutralność i wartości akademickie, w: Leszek Kołakowski, Moje stuszne poglady na wszystko, Znak, Kraków.

Krajewski Marek, 2014, Czynnik ludzki. Polityka prostoty i nasze relacje z technologia (https://www. academia.edu/9247663/Czynnik_ludzki._Polityka_prostoty_i_nasze_relacje_z_technologią [30.01.2015]).

Latour Bruno, Woolgar Steve, 1986, Laboratory Life: The Construction of Scientific Facts, Princeton University Press, New Jersey.

Lukes Steven, 2012, Durkheim. Życie i dzieło, tłum. Ewa Klekot, Ewa Szul-Skjoeldkrona, Oficyna Naukowa, Warszawa.

Mills Charles Wright, 2008, Wyobraźnia socjologiczna, tłum. Marta Bucholc, Wydawnictwo Naukowe PWN, Warszawa.

Osterhammel Jürgen, 2013, Historia XIX wieku. Przeobrażenie świata, tłum. różni, Wydawnictwo Poznańskie, Poznań.

Pauwels Louis, 2011, Zwrot wizualny $w$ badaniach $i$ komunikacji wiedzy. Kluczowe problemy rozwijania kompetencji wizualnej $w$ naukach spotecznych, tłum. Maciej Frąckowiak, w: Maciej Frąckowiak, Krzysztof Olechnicki (red.), Badania wizualne w działaniu, Fundacja Bęc Zmiana, Warszawa. 
Szacki Jerzy, 1991, Intelektualiści pomiędzy kultura i polityka, w: Jerzy Szacki, Dylematy historiografii idei oraz inne szkice $i$ studia, Wydawnictwo Naukowe PWN, Warszawa.

Zaremba Łukasz, 2011, O różnych możliwościach archiwum wizualnego, „Kultura Współczesna”, nr 4.

\section{BRINGING THE INVISIBLE TO PUBLIC LIGHT: \\ THE VISUAL ARCHIVE AND THE PRACTICE-ORIENTED INTELLECTUAL}

Summary

This article was written on the basis of the project 'See Culture: The Archive of Visual Materials from Research into Culture in Poland' conducted in 2014. It speaks of the internet creation of a social database using visual materials - the Visual Archive (archiwumwizualne.pl). The authors present their findings from interviews with members of the research teams and directors of the projects that were included in the internet archive. These primarily concern the various approaches and research practices of the interlocutors and their definitions of visual material's potential as a tool in social research. The profiles of the researchers presented earlier is then compared to the category of the practice-oriented intellectual, which broadens the classical understanding of the intellectual and points to an emerging manner of thinking about research practice in contemporary social sciences. The usefulness of the Visual Archive for the practice-oriented intellectual is indicated.

\section{Key words/słowa kluczowe}

visual archive / archiwum wizualne; intellectuals / intelektualiści; practice-oriented intellectual / intelektualista-praktyk; social knowledge / wiedza społeczna; culture research / badania kultury; quality research practice / praktyka badań jakościowych; visual research / badania wizualne 